\title{
STRATEGI PENGEMBANGAN KAWASAN WISATA ALAM PULISAN KABUPATEN MINAHASA UTARA
}

\author{
Renardi Ariowibowo \\ Tommy Lolowang \\ Leonardus Rengkung
}

\begin{abstract}
This study aimed to describe the potential and opportunities of Tourism Region Pulisan, identify any weaknesses and threats, and define management strategies of Pulisan Coastal Region. This research used descriptive method to interpret the data. This research was conducted at the Village of Pulisan, East Likupang Sub-district, North Minahasa Regency, North Sulawesi Province which began in March to August 2016. The sampling technique used purposive sampling and used Theory of Tourism System. Respondents in this study is the government of North Minahasa Regency. The data used in this study are primary data and secondary data. This study uses a model of SWOT analysis (Strengths, Weaknesses, Opportunities, Threats) factors predefined both from the view of experts as well as existing regulation. Then analyze the internal and external factors that are arranged in a matrix of IFAs (Internal Factor Analysis) and EFAS (External Factor Analysis). Research using SWOT analysis weights and scores are determined based on the analysis of data obtained from the respondents. The results showed that the tourism area is Pulisan Tourism Regions with high natural potential and much in demand by tourists. Although the location is not too wide but has many interesting attractions Tourism Region of Pulisan natural appeal to different types of travelers with different motivations. Development undertaken by the community with the coaching is done by the Department of Tourism and Culture of North Minahasa provide a change of design in terms of tourist facilities. Rearrangement taking into account the priority needs of tourists in the tourism area, this will greatly affect its development, so that tourists and travelers can feel the value of Marine Tourism Region at an affordable price. Growth strategies that are used to provide benefits for local residents. High tourist visits every weekend is expected to give local residents the ability to develop, it need guidance from relevant agencies to provide more targeted development.
\end{abstract}

Keywords: SWOT, Strategy of Development, Natural Tourism Region. Pulisan Village, North Minahasa

\section{ABSTRAK}

Penelitian ini bertujuan untuk mendeskripsikan potensi dan peluang Kawasan Wisata Pulisan, mengindentifikasi kelemahan dan ancaman, dan menentukan strategi pengelolaan Kawasan Pantai Pulisan. Penelitian ini menggunakan metode penelitian deskriptif untuk menginterpretasikan data. Penelitian ini dilakukan pada Kelurahan Pulisan, Kecamatan Likupang Timur, Kabupaten Minahasa Utara, Propinsi Sulawesi Utara yang dimulai pada bulan Maret sampai Agustus 2016. Teknik sampling menggunakan tehnik purposive sampling dan menggunakan Teori Sistem Pariwisata. Responden dalam penelitian ini adalah Pemerintah Kabupaten Minahasa Utara. Data yang digunakan dalam penelitian ini adalah data primer dan data sekunder. Penelitian ini menggunakan model analisis SWOT (Strengths, Weaknesses, Opportunity, Threats) dengan faktor-faktor yang sudah ditentukan sebelumnya baik dari pandangan para ahli serta peraturan perundangan yang ada. Kemudian menganalisis faktor internal dan eksternal yang disusun dalam matriks IFAS (Internal Factor Analysis) dan EFAS (External Factor Analysis). Penelitian menggunakan analisis SWOT ini bobot dan skor ditentukan berdasarkan analisis data yang diperoleh dari responden. Hasil penelitian menunjukkan bahwa Kawasan Wisata Pulisan adalah Kawasan Wisata dengan potensi alam yang tinggi dan banyak diminati oleh wisatawan. Walaupun dengan Lokasi yang tidak terlalu luas namun banyak memiliki atraksi yang menarik Kawasan Wisata alam Pulisan menarik bagi berbagai jenis wisatawan dengan motivasi yang berbeda pula. Pengembangan yang dilakukan oleh masyarakat dengan pembinaan yang dilakukan oleh Dinas Pariwisata dan Kebudayaan Minahasa Utara memberikan perubahan dari segi desain fasilitas wisata. Penataan ulang dengan mempertimbangkan prioritas akan kebutuhan wisatawan di Kawasan Wisata ini akan sangat berpengaruh pengembangannya, sehingga wisatawan dan pelancong dapat merasakan value atau dari sebuah Kawasan Wisata Bahari dengan harga yang terjangkau. Strategi pertumbuhan yang digunakan memberikan manfaat bagi warga setempat. Kunjungan wisatawan yang tinggi setiap akhir pekan diharapkan bisa memberikan warga setempat kemampuan untuk mengembangkan, hanya saja perlu pembinaan dari dinas terkait untuk memberikan pengembangan yang lebih terarah.

Kata Kunci: SWOT, Strategi Pengembangan, Kawasan Wisata Alam. Desa Pulisan, Minahasa Utara 


\section{PENDAHULUAN}

Dewasa ini pariwisata sudah merupakan penggerak pembangunan di Indonesia. Pembangunan pariwisata yang dilakukan selama ini memberikan pengaruh positif baik bagi masyarakat maupun pemerintah. Adapun tujuan pengembangan pariwisata yang berkelanjutan menurut United Nations World Tourism Organisations (UNWTO) terdiri dari lima pilar yaitu (1) kebijakan mengenai pariwisata dan pemerintahanyang baik; (2) ekonomi, investasi dan daya saing; (3) meliputi ketenagakerjaan, pekerjaan yang layak dan human capital; (4) pemberdayaan masyarakat dan (5) kelestarian alam dan lingkungan budaya.Tujuan kepariwisataan yang tercantum dalam UndangUndang Nomor 10 Tahun 2009 menyebutkan bahwa meningkatkan pertumbuhan ekonomi, meningkatkan kesejahteraan rakyat, menghapus kemiskinan, menghapus pengangguran, melestarikan alam lingkungan dan sumber daya; memajukan kebudayaan; mengangkat citra bangsa, memupuk rasa cinta tanah air, memperkukuh jati diri dan kesatuan bangsa, dan mempererat persahabatan antar bangsa.

Pariwisata Indonesia masih mengandalkan Bali sebagai tujuan (destinasi) yang paling banyak dikunjungi oleh wisatawan mancanegara dengan jumlah kunjungan sebanyak 3.731 .735 wisatawan, kemudian peringkat kedua Jakarta dan Batam padaperingkat ketiga pada tahun 2014. Destinasi wisata unggulan lainnya adalah Candi Borobudur, Mandalika, Labuan Bajo, Bromo Tengger Semeru, Kepulauan Seribu, Danau Toba, Wakatobi, Tanjung Lesung, Morotai dan Tanjung Kelayang. Gambar 1 menunjukkan kunjungan wisatawan mancanegara ke Indonesia pada tahun 1997 sampai dengan 2014, yang masuk melalui empat bandara utama yakniNgurah Rai Bali, Soekarno Hatta Jakarta, Hang Nadim Batam dan Kuala Namu Medan sertabandara-bandaralainnya.

Bandara lainnya: merupakan bandara-bandara selain bandara pintu gerbang utama termasuk diantaranya Bandara Sam Ratulangi Sulawesi Utara.

Kuncoro dalam Nurman (2015) mengemukakan secara umum, pemerintah daerah dan seluruh komponen masyarakat mengelola berbagai sumber daya yang ada dan membentuk pola kemitraan, untuk menciptakan suatu lapangan kerja baru dan merangsang pengembangan kegiatan ekonomi dalam daerah, amat tergantung dari masalah fundamental yang dihadapi oleh daerah tersebut. Bagaimana daerah mengatasi masalah fundamental yang dihadapi ditentukan oleh strategi pembangunan yang dipilih. Dalam konteks inilah pentingnya merumuskan visi dan misi dan memilih strategi yang tepat. Pemerintah Sulawesi Utara sebagai pelaksana desentralisasi, dekonsentrasi dan pembantuan lainnya serta kewenangan kabupaten Kota yang diserahkan kepada provinsi di bidang pariwisata, memiliki visi: Terwujudnya Sulawesi Utara yang berbudaya, dan sebagai salah satu destinasi pariwisata yang berdaya saing, serta mampu meningkatkan kesejahteraan masyarakat menuju pintu gerbang Indonesia di kawasan Asia dan Pasifik:

(1) Mempunyai pedoman pembangunan dan pengembangan kebudayaan dan kepariwisataan daerah yang dijabarkan dalam Rencana Induk Pembangunan Kepariwisataan Provinsi (RIPKP);

(2) Melestarikan nilai, melestarikan keragaman dan kekayaan budaya dalam rangka memperkuat jati diri dan karakter bangsa;

(3) Mengembangkan destinasi pariwisata yang berdaya saing dan berkelanjutan;

(4) Meningkatkan kunjungan wisatawan dan menerapkan pemasaran yang bertanggung jawab;

(5) Mengembangkan industri pariwisata yang berdaya saing;

(6) Mengembangkan sumber daya kebudayaan dan pariwisata;

(7) Menciptakan tata pemerintahan yang responsif transparan dan akuntabel.

Pembangunan pariwisata di Sulawesi Utara menggunakan model perencanaan sintesa dengan rencana pembangunan jangka menengah.Kabupaten Minahasa Utara yang merupakan pemekaran dari kabupaten Minahasamengandalkan wisata alam sebagai obyek dan daya tarik wisata. Data pada Tabel 1 yang diperoleh dari BPS mengungkapkan bahwa Minahasa Utara mempunyai beberapa obyek wisata yang menarik untuk dikunjungi.

Kunjungan wisatawan ke Sulawesi Utara pada tahun 2009 yang mencapai 16.700 orang merupakan kunjungan wisatawan paling tinggi selama tujuh tahun terakhir. Pada 2007 yang mencapai 12.197 orang dan pada tiga tahun berturut-turut dari 2011 sampai dengan 2013 yakni11.876 orang, 11.694 orang, dan 11.873 
orang mengalami stagnasi.Kunjungan wisatawan ke kabupaten Minahasa Utara mencapai 11.873 orang wisatawan lokal dan 9.026 wisatawan asing pada tahun 2013. Sebagian besar wisatawan ini mengunjungi destinasi pantai.

Kabupaten Minahasa Utara memiliki 32 daya tarik wisata sebagaimana tercantum dalam Tabel 1, dengan rincian wisata budaya, wisata religi, dan juga wisata pantai. Pemerintah Sulawesi Utara melalui Perda Nomor 1 tahun 2014 tentangRencana Tata Ruang Wilayah Kabupaten Sulawesi Utara tahun 2013 2033mencanangkankawasanwisata di Sulawesi Utaratermasuk yang terdapat di KabupatenMinahasa Utara, salah satunya adalah KawasanWisata Pantai Pulisan sebagai Kawasan Wisata. Penetapan Pulisan sebagai kawasan wisata berdampak pada meningkatnya kunjungan wisata kewilayah tersebut. Hal ini juga ditunjang dengan perkembangan teknologi informasi yang ada saat ini, yang secara tidak langsung telah membantu memperkenalkan dan mempromosikan Kawasan Pantai Pulisanmelalui media sosialmaupun media elektronik. Informasi tentang Pantai Pulisan melalui media ini yang telah memberikan efek positif, yaitu dengan meningkatnya kunjungan wisatawan dariwaktu kewaktu, terutama pada saat akhir pekan dan masa liburan. Selain Kawasan Pantai Pulisan di Kecamatan Likupang Timur terdapat beberapa pantai yakni: Pantai Surabaya di DesaWineru, Casa Bayo Resort di DesaMaen, Pantai Paal di Desa Marinsow, dan Pantai Kalinaung di Desa Kalinaung. Letaknya yang berada dalam satugaris pantai dan satu wilayah, merupakan suatu tantangan untuk setiap pengelola kawasan wisata agar dapat menarik perhatian wisatawan.

Masing-masing pantai memiliki keindahan tersendiri yang tidak bisa disamakan satudengan yang lain, terlebih kawasan pantai di Desa Maen Casa Baio Resort telah dikelola secara professional oleh pengusaha dari luar Minahasa Utara. Sementara keempat kawasan pantai lainnya yakni Pantai Surabaya, pantai Paal, Pantai Pulisan dikelola secara swadaya masyarakat bersama dengan pemerintah desa.

Kawasan Pantai Pulisan memiliki keindahan yang unik dimana topografinya berbukit dan berpasir putih, serta terdiri dari beberapa pantai, dan memiliki laut yang landai sehingga aman bagi anak-anak. Keindahan alamnya dilengkapi dengan beberapa tempat yang cocok untuk dijadikan spot untukberfoto. Keunikan inilah yang menyebabkan makin meningkatnya kunjungan wisata.

Menurut Inskeep dalam John Walker 2010 Permintaan dalam pariwisata adalah penggunaan atraksi, fasilitas dan layanan dalam wisata. Sedangkan factor-faktor penawarannya adalah transportasi, infrastruktur, jaringan listrik dan saluran air dan atraksi, akomodasi, fasilitas pelayanan dan elemen industri.

Peningkatan kunjungan wistawan ke kawasan ini dalamwaktu yang relative singkat ini, meningkatkan kebutuhan berbagai sarana pelengkap suatu daerah tujuan wisata, antara lain akses menuju lokasi wisata, sarana dan prasarana baik untuk duduk menikmati keindahan alamnya, warung yang menyediakan makanan dan minuman, dan perlengkapan untuk mandi di pantai seperti pakaian, alat pelampung, snorkeling, sertasarana sanitasi dan lain-lain. Berbagai sarana dan prasarana yang dibutuhkan oleh wisatawan ditanggapi oleh masyarakat dengan mengadakan sarana tersebut secara bergotong royong dan swadaya sesuai dengan kemampuan masyarakat, bersama dengan pemerintah desa setempat. Di sisi lain obyek atau kawasan wisata perlu ada perubahan untuk memberikan pengalaman bagi wisatawan karena tourist yang berdatangan dan tour operator bisa saja melakukan kunjungan dan apabila belum ada pengembangan maka bisa saja tour operator beralih ke obyek wisata lain yang jauh lebih menarik dengan biaya yang relatif sama karena BPW akan selalu mencari obyek wisata unggulan. Perkembangan kunjungan wisatawan ke Pantai Pulisan secara perlahan telah merubah mata pencaharian sebagian masyarakat yang ada di Desa Pulisan, dari nelayan dan petani penggarap serta pekerja serabutan menjadi pengusaha atau pun pekerja di kawasan tersebut. Perahu yang biasa digunakan sebagai sarana untuk menangkap ikan telah dialih fungsikan sebagai sarana penghubung antara satu pantai dengan pantai lainnya di Kawasan Wisata Pantai Pulisan. Pengalihan profesi masyarakat di Desa Pulisan ini pun telah merubah kebiasaan dan cara hidup masyarakat, yang pada akhirnya telah merubah perekonomian desa ini dari yang bertumpu pada sektor pertanian dan kelautan menjadi ke sektor pariwisata. Selain itu, pengelolaan di Kawasan Pantai Pulisan berbeda dengan ketiga pantailainnya, dimana pengelolaannya melibatkan masyarakat desa dan hanya oleh masyarakat desa, serta diatur oleh pemerintah desa. 


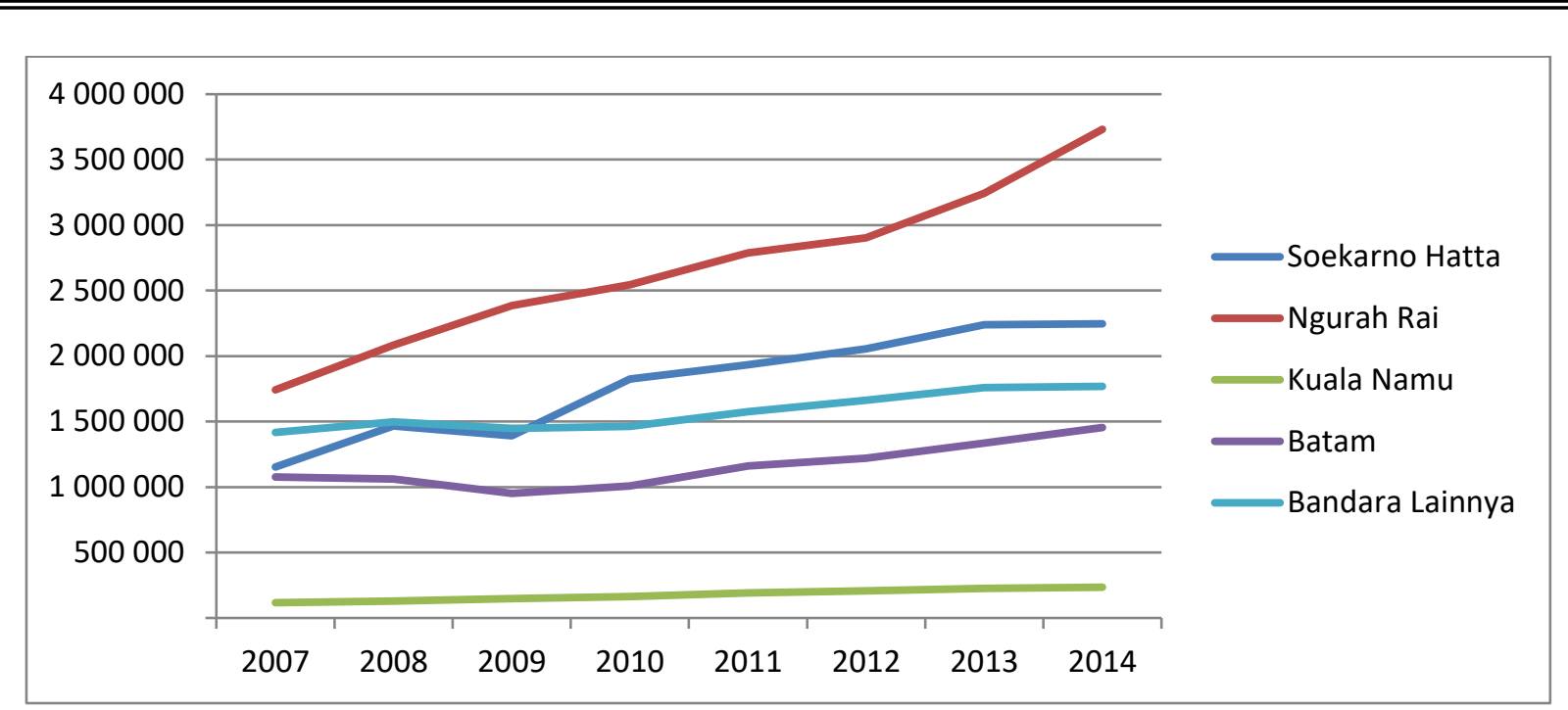

Tabel 1 Obyek Wisata di Minahasa Utara

\begin{tabular}{lll}
\hline District & $\begin{array}{c}\text { Desa/Kelurahan } \\
\text { Rural/Urban }\end{array}$ & Objek / \\
Object
\end{tabular}

Sumber: BPS (2016) 


\section{Rumusan Masalah}

Kawasan Wisata Pulisan yang terletak berdekatan dengan kawasan wisata lainnya (Kawasan Wisata Pantai Pal) memerlukan strategi yang tepat sehingga Kawasan Wisata ini dapat terus dikunjungi oleh wisatawan domestic dan mancanegara. Kawasan Wisata yang telah membuka lapangan pekerjaan bagi penduduk sekitar dan memberikan manfaat secara ekonomi akan bisa berkembang dengan mempertimbangkan factor-faktor internal dan eksternal seperti potensi alam dan pengelolaan dari kawasan wisata ini.

\section{Tujuan Penelitian}

Penelitian ini bertujuan untuk

1. Mendeskripsikan Potensi dan Peluang Kawasan Wisata Pulisan

2. Mengindentifikasi kelemahan dan anacaman

3. Menentukan strategi pengelolaan Kawasan Pantai Pulisan

\section{ManfaatPenelitian}

Penelitian inidiharapkan dapat memberikan manfaat bagi:

1. Bagi Pengelolaan Kawasan Wisata

2. Bagi pemerintah Desa Pulisan dalam mengelola KawasanWisata

\section{METODOLOGI PENELITIAN}

\section{Lokasi dan Waktu Penelitian}

Penelitian ini dilakukan pada Kelurahan Pulisan Kecamatan Likupang Timur Kabupaten Minahasa Utara, Propinsi Sulawesi Utara. Penelitian ini dimulai pada bulan Maret-Agustus 2016.

\section{Teknik sampling}

Teknik sampling yang digunakan adalah sampling purposif dengan menggunakan teori sistem pariwisata. Responden dalam penelitian ini adalah Pemerintah Kabupaten Minahasa Utara.

\begin{tabular}{clc}
\hline \hline No & \multicolumn{1}{c}{ Responden } & $\begin{array}{c}\text { Jumlah } \\
\text { Responden }\end{array}$ \\
\hline 1 & $\begin{array}{l}\text { Dinas Pariwisata dan } \\
\text { Kebudayaan }\end{array}$ & 1 \\
2 & $\begin{array}{l}\text { Pemerintah Desa } \\
\text { Pulisan }\end{array}$ & 3 \\
3 & $\begin{array}{l}\text { Penyedia Jasa Desa } \\
\text { Pulisan }\end{array}$ & 11 \\
4 & Wisatawan & 9 \\
\hline
\end{tabular}

\section{Sumber Data dan Pengumpulan Data}

\section{Sumber Data}

Data yang digunakan dalam penelitian ini adalah data primer dan data sekunder. Data Primer diperoleh dengan cara wawancara dan membagikan kuesioner kepada wisatawan, pengusaha pariwisata, aparat pemerintah setempat. Data sekunder diperoleh dari Kantor Desa Pulisan, Kantor Kecamatan Likupang Timur, Dinas Pariwisata Kabupaten Minahasa Utara, Badan Pusat Statistik, dan Pusat Penelitian dan Pengembangan Kabupaten Minahasa Utara.

\section{Teknik Pengumpulan Data Penelitian}

Pengumpulan data dilakukan dengan berbagai cara antara lain wawancara, Observasi dan Kuisioner. Wawancara yang dimaksud dalam penelitian adalah wawancara dengan Dinas Pariwisata Kabupaten Minahasa utara, yang menjadi respondem adalah Kepala Seksi Dinas Pariwisata dan Kebudayaan. Selanjutnya untuk mendapatkan data dari wisatawan yang datang peneliti menggunakan kuesioner dengan variabel yang telah ditentukan sebelumnya.

\section{Definisi Operasional Variabel}

Definisi operasional adalah variabel penelitian dimaksudkan untuk memahami arti setiap variabel penelitian sebelum dilakukan analisis. Analisis yang digunakan dalam penelitian ini adalah Analisis SWOT yang terbagi atas faktor internal dan faktor eksternal dengan sub faktor seperti yang dijelaskan dibawah ini. 


\section{Faktor Internal}

1. Atraksi wisata, acara dan kegiatan Atraksi wisata, acara dan kegiatan ini adalah fitur-fitur daerah yang berbasis alami dan buatan manusia yang menarik bagi wisatawan dan merupakan alasan mereka kunjungi. Keunikan pusat pembelanjaan, layanan terbaik, tempat bersejarah, museum, fitur alam yang luar biasa, festival budaya yang unik, konvensi/konferensi dan partisipasi dalam kegiatan petualang alam terbuka.

2. Pemasaran pariwisata, melibatkan bagaimana individu, kelompok masyarakat mengatur merencanakan dan menjual value sebuah destinasi sebuah wisatawan sebelum ada di destinasi.

3. Infrastruktur pariwisata, termasuk fasilitas yang tersedia bagi wisatawan dalam perjalanan mereka ke destinasi, dan saat berkunjung ke suatu daerah seperti jalan, area petunjuk arah, air, listrik, telepon, internet dan fasilitas rekreasi yang digunakan dalam atraksi wisata budaya atau kegiatan walaupun wisatawan tidak secara langsung membayar untuk fasilitas ini tetapi infrastruktur yang kurang atau berkualitas buruk akan menentukan apakah wisatwaan akan menghabiskan waktu mengunjungi daerah lain atau mendorong orang lain untuk mengunjungi suatu daya tarik wisata.

\section{Faktor Eksternal}

a. Kebijakan Pemerintah

Kebijakan Pemerintah baik pemerintah Provinsi Sulawesi Utara, Kabupaten Minahasa Utara dan juga pemerintah Kecamatan Likupang Timur dan pemerintah Desa Pulisan di bidang pariwisata.

Keterlibatan stakeholder dalam penyusunan program pengembangan, pengesahan serta pelaksanaan program pengembangan Kawasan Pantai Pulisan

b. Kondisi Perekonomian Desa

Bagaimana pariwisata memberikan dampak bagi kondisi perekonomian penduduk Desa Pulisan. Dampak pariwisata terhadap pendapatan penduduk Desa Pulisan, baik yang berperan secara langsung maupun tidak langsung dalam kegiatan di Kawasan Pantai Pulisan. Yang dimaksud dengan yang terlibat langsung adalah penduduk yang mata pencaharian utamanya di Kawasan Pantai Pulisan dan yang tidak terlibat yang mata pencahariannya bukan di Kawasan Pantai Pulisan. Penyerapan tenaga kerja yang diakibatkan oleh kegiatan pariwisata di Kaasan Pantai Pulisan dan terbentuknya usaha kecil yang diakibatkan dari kegiatan pariwisata di Kawasan Pantai Pulisan.

c. Kelestarian Alam dan Budaya

Perhatian utama dalam keberlanjutan alam dan budaya adalah bagaimana pariwisata menyingkapi perubahan iklim yang ada dan mempertahankan budaya yang diwariskan oleh leluhur.

\section{Analisis Data}

Data yang diperoleh dianalisis secara tabelaris dan deskriptif serta analisis SWOT. SWOT (Strengths, Weaknesses, Opportunity, Threats) dengan faktor-faktor yang sudah ditentukan sebelumnya baik dari pandangan para ahli serta peraturan perundangan yang ada. Kemudian menganalisis faktor internal dan eksternal yang disusun dalam matriks IFAS (Internal Factor Analysis) dan EFAS (Eksternal Factor Analysis). Hasil analisis ini akan memberikan suatu pernyataan strategi yang dilakukan oleh stakeholder yang ada, pada penelitian ini masyarakat desa yang berperan sebagai pengelola kawasan serta pemerintah desa setempat.

\section{Model Analisis Data}

Penelitian ini menggunakan model analisis SWOT. Penelitian menggunakan analisis SWOT ini bobot dan skor ditentukan berdasarkan analisis data yang diperoleh dari responden. 


\begin{tabular}{|c|c|c|c|}
\hline $\begin{array}{c}\text { Faktor-Faktor Strategis } \\
\text { Internal }\end{array}$ & Bobot & Rating & $\begin{array}{c}\text { Skor Pembobotan } \\
\text { Bobot x Rating }\end{array}$ \\
\hline $\begin{array}{l}\text { Kekuatan } \\
\text { (strength) } \\
\begin{array}{ll}\text { 1. } & \text { Kekuatan } 1 \\
\text { 2. } & \text { Kekuatan } 2 \\
\end{array}\end{array}$ & $\begin{array}{l}\text { Bobot Kekuatan } 1 \\
\text { Bobot kekuataan } 2\end{array}$ & $\begin{array}{l}\text { Rating } 1 \\
\text { Rating } 2\end{array}$ & \\
\hline Jumlah & $\mathrm{a}$ & & $\mathrm{b}$ \\
\hline $\begin{array}{l}\text { Kelemahan } \\
\text { (kelemahan) } \\
\text { 1. Kelemahan } 1 \\
\text { 2. Kelemahan } 2\end{array}$ & $\begin{array}{l}\text { Bobot Kelemahan } 1 \\
\text { Bobot Kelemahan } 2\end{array}$ & $\begin{array}{l}\text { Rating } 1 \\
\text { Rating } 2\end{array}$ & \\
\hline Jumlah W & $\mathrm{c}$ & & $\mathrm{d}$ \\
\hline & $\mathrm{a}+\mathrm{c}=1$ & & $b+d$ \\
\hline
\end{tabular}

\section{HASIL DAN PEMBAHASAN}

\section{Gambaran Umum Lokasi Penelitian}

Lokasi penelitian yang diteliti memiliki karakteristik masing-masing. Kawasan Wisata Pulisan yang memiliki beberapa pantai fasilitas pendukung wisata juga atraksi wisata pendukung seperti olah raga air. Berikut ini adalah gambaran mengenai lokasi penelitian.

\section{Deskripsi Desa Pulisan}

Kawasan wisata Pulisan terletak di Kabupaten Minahasa Utara Kecamatan Likupang Timur sekitar $46 \mathrm{~km}$ dari pusat Kota Manado dan $25 \mathrm{~km}$ dari Airmadidi. Kawasan Wisata Pulisan berbatasan sebelah utara dengan Laut Sulawesi, selatan dengan Desa Marinsow. Letak astronomi Pulisan adalah 1,66984 ${ }^{\circ}$ Lintang Utara dan $125,14574^{\circ}$ Bujur Timur Luas Kawasan Wisata ini 3,02 $\mathrm{km}^{2}$

Pantai Pulisan adalah pantai yang memiliki garis pantaisepanjang 491,95 $\mathrm{m}$ dan luas lahan yang dapat dimanfaatkan $5.157,03 \mathrm{~m}^{2}$. Lahan yang ada dimanfaatkan untuk pondokpondok bagi wisatawan yang berkunjung, luasnya $30 \mathrm{~m}^{2}$. Luasan adalah luas yang diijinkan oleh KepalaDesa Pulisan. Pulisan berada di wilayah pesisir dengan ketinggian $100 \mathrm{~m}$ diatas permukaan laut terdiri dari 4 batas wilayah sebagai berikut.

Sebelah Utara : Selat Bangka

Sebelah Timur : Desa Kinunang

Sebelah Selatan : DesaMarinsow

Sebelah Barat : Selat Bangka

\section{Sejarah Desa}

Asal usul Desa Pulisan berasal dari masyarakat kepulauan Sangihe, Siau Biaro, Tagulandang. Pada tahun 1930 mereka menetap di dusun dengan sebutan Timbelang yang sekarang ini disebut dengan pantai besar. Pada tahun 1940 masyrarakat di Desa Timbelang berinisiatif untuk beralih tempat yang sekarang disebut dengan Desa Pulisan. Saat itu Dusun Pulisan termasuk dalam wilayah administratif Desa Maen.

Kemudian pada tahun 1957 Desa Pulisan dimekarkan dari Desa Maen. Desa Pulisan adalah desa yang terletak di Semenanjung pulau Sulawesi bagian utara dimana terdapat pertemuan dua arah angin barat dan timur dan putaran air laut tersebut dinamakan oleh penduduk Pulisan. Para nelayan dan penduduk yang ingin menyeberang baik dari dua arah bilamana terjadi air pasang dan surut mereka akan menunggu sampai air di lautan tenang, atau disebut Pulis tadi yang disebut oleh penduduk daerah Pangampale Lisange artinya menunggu saat yang teduh.

Dahulu sampai sekarang tanjung Pulisan yang terdapat beribu-ribu putaran air laut tadi, merupakan areal tangkap para nelayan setempat dan nelayan lainnya. Oleh karena terdapat banyak ikan berukuran besar alat tangkap nelayan yang dipakai saat itu sering terlepas atau yang biasa disebut para penduduk dalam bahasa daerah sebagai Napulise yang artinya terlepas, dari ketiga cerita rakyat ini disimpulkanlah nama desa menjadi desa Pulisan. 
Selanjutnya pada tahun 2011 sesuai dengan SK Hukum Tua Benhar Djarang dibentuk Panitia Pemekaran Desa, dan pada bulan Desember 2012 Desa Pulisan dimekarkan menjadi dua desa yaitu: Desa Pulisan dan Desa Kinunang.

\section{Pemerintah Desa}

Desa Pulisan dipimpin oleh seorang kepala desa yang disebut dengan Hukum Tua yang berperan dalam kegiatan pembangunan, pelayanan masyarakat dan keamanan seperti yang tercantum dalam Tabel 2 .

Hukum Tua sejak tahun 1957 sampai dengan tahun 1984 ditunjuk oleh pemerintah kabupaten dan disebut Pejabat Hukumtua. Pemilihan hukumtua secara langsung oleh masyarakat, yang dilaksanakan 5 tahun sekali, sejak tahun 1984 sampai dengan sekarang.

\section{Luas Desa Pulisan dan Penggunaan Lahan Desa}

Desa Pulisan berada di Kecamatan Likupan Timur, dimana di Kecamatan Likupang Timur terdapat 19 desa.Luas Wilayah Likupang Timur 1.152,61 kilometer persegi $\left(\mathrm{km}^{2}\right)$. Desa Pulisan adalah desa dengan luas wilayah ketiga terkecil dari 19 desa yang ada, dapat dilihat pada Tabel 5

Lahan di Desa Pulisan digunakan untuk pekarangan, perkebunan, hutan dan lainnya. Desa ini tergolong desa yang kecil, luas pemukiman $3,2 \mathrm{~km}^{2}$, hanya sekitar 2 persen dari total luas wilayah kecamatan Likupang Timur yaitu 152, $61 \mathrm{~km}^{2}$ (BPS, 2015).Pekarangan yang digunakan hanya $3,20 \mathrm{~km}^{2}$. Perkebunan yang digunakan $4,02 \mathrm{~km}^{2}$. Hutan $3,50 \mathrm{~km}^{2}$ dan lainnya $2,50 \mathrm{~km}^{2}$.

Tabel 2. Kepala Desa Pulisan 1957-sekarang

\begin{tabular}{llclc}
\hline No & Nama & Masa Jabatan & Status & Keterangan \\
\hline $\mathbf{1}$ & Alfianus Togelang & $1957-1962$ & Pejabat & 2Jaga \\
$\mathbf{2}$ & Yohanis Marendes & $1962-1968$ & Pejabat & 2Jaga \\
$\mathbf{3}$ & Fhilips Ganap & $1968-1969$ & Pejabat & 2Jaga \\
$\mathbf{4}$ & Yunus Bintang & $1969-1970$ & Pejabat & 2Jaga \\
$\mathbf{5}$ & Adolf Wodi & $1970-1972$ & Pejabat & 2Jaga \\
$\mathbf{6}$ & Yan Laleno & $1972-1976$ & Pejabat & 2Jaga \\
$\mathbf{7}$ & Daniel Boyoh & $1976-1978$ & Pejabat & 2Jaga \\
$\mathbf{8}$ & S.M. Rondonuwu & $1978-1982$ & Pejabat & 2Jaga \\
$\mathbf{9}$ & Christian kalangit & $1982-1984$ & Pejabat & 2Jaga \\
$\mathbf{1 0}$ & Ferdinan Natari & $1984-1999$ & Terpilih & 2Jaga \\
$\mathbf{1 1}$ & Herman Mondow & $1999-2000$ & Terpilih & 2Jaga \\
$\mathbf{1 2}$ & Jon Mot Daleroh & 2000 & Plh & 2Jaga \\
$\mathbf{1 3}$ & Marthin Sadedo & $2000-2007$ & Terpilih & 3Jaga \\
$\mathbf{1 4}$ & Benhar Djarang & $2007-2014$ & Terpilih & 3Jaga \\
$\mathbf{1 5}$ & Vekli Ansa & $2014-2020$ & Terpilih & 3Jaga \\
\hline \hline Sumber: Profin & & &
\end{tabular}

Sumber: Profil Desa Pulisan (2015) 
Tabel 3. Luas Desa-Desa di Likupang Timur

\begin{tabular}{lrc}
\hline Desa & Luas & Presentase \\
\hline Sarawet & 10,27 & $7 \%$ \\
Likupang Dua & 2,50 & $2 \%$ \\
Likupang Satu & 5,00 & $3 \%$ \\
Wineru & 7,50 & $5 \%$ \\
Maen & 7,00 & $5 \%$ \\
Winuri & 11,46 & $8 \%$ \\
Pinenek & 40,25 & $26 \%$ \\
Rinondoran & 3,89 & $3 \%$ \\
Kalinaun & 4,18 & $3 \%$ \\
Marinsow & 14,39 & $9 \%$ \\
Pulisan & 3,02 & $2 \%$ \\
Lihunu & 14,26 & $9 \%$ \\
Kahuku & 3,67 & $2 \%$ \\
Libas & 6,42 & $4 \%$ \\
Likupang Kampung Ambong & 5,00 & $3 \%$ \\
Resettlemen & 2,50 & $2 \%$ \\
Kinunang & 5,00 & $3 \%$ \\
Ehe & 6,30 & $4 \%$ \\
\hline Total & 1152,61 & \\
\hline
\end{tabular}

Sumber BPS (2015)

Tabel 4. Jenis dan Luas PenggunaanLahan di Desa Pulisan Tahun 2016

\begin{tabular}{lc}
\hline Jenis Penggunaan & Luas $\left(\mathrm{km}^{2}\right)$ \\
\hline Pekarangan & 3,20 \\
Perkebunan & 4,02 \\
Hutan & 3,50 \\
Lainnya & 2,50 \\
\hline
\end{tabular}

Sumber: Profil Desa Pulisan (2016)

\section{Pariwisata}

Kawasan Wisata Pulisan terdiri atas beberapa pantai, yakni Pantai Besar Pulisan, Pantai Goa, Pantai Pasir Panjang dan Pulisan II yang terletak di Desa Kinunang.Pantai tersebut terletak berurutan sepanjang teluk di Desa Pulisan sampai ke Desa Kinunang, semua pantai yang ada ini sering dikunjungi oleh wisatawan.Masing-masing pantai memiliki keunikan baik dari topografinya, maupun kedalaman airnya, sedangkan pasirnya semuanya berwarna putih. Pantai-pantai tersebut tidak terhubung oleh jalan darat satu dengan lainnya, tetapi dengan menggunakan perahu motor tempel dari Pantai Besar. Jarak antara pantai besar dengan pantai-pantai lainnya tidak begitu jauh, yang terdekat Pantai Goa dengan waktu tempuh 5 menit perjalanan menggunakan perahu bermotor, kemudian Pantai Panjang sekitar 10 menit dan Pantai Pulisan II sekitar 15
menit.Tarif yang dikenakanuntuk pengunjung ke pantai Goa, Pasir Panjang dan Pulisan II Rp20.000/orang dengan kapasitas 7 orang. Perahu yang digunakan adalah perahu bercadik dengan panjang rata-rata 4(empat) meter dan bertenaga mesin bensin 9(sembilan) pk yang dimodifikasi menjadi mesin perahu.

Wisatawan berkunjungke Kawasan Pantai Pulisan pengunjung hanya bisa melalui jalan menuju pantai dari Desa Pulisan, dan setiap pengunjung dikenakan biaya masuk yang besarannya disesuaikan dengan kendaraan yang ditumpanginya. Jenis kendaraan yang masuk Kawasan Wisata Pulisan dikategorikan dalam 3 jenis kendaraan yakni: kendaraan roda 2, kendaraan roda 4 (mobil) dan bus. Tarif parkir sekaligus sebagai tarif masuk kawasan menurut jenis kendaraan, yakni Rp5.000 untuk sepeda motor, Rp15.000 untuk mobil sejenis serta Rp30.000 untuk bus dan truk. 
Di sepanjang garis pantai terdapat pondok-pondok atau gazebo tempat wisatawan duduk sambil menikmati keindahan pantai, dimana pondok yang ada dengan berbagai ukuran dan jenis bangunan. Harga sewa pondok disesuaikan dengan ukuran pondok, ukuran 16 meter persegi, 6,25 meter persegi dan 2,25 meter persegi, masing-masing Rp.250.000,00 dan Rp.150.000,00 per hari pada hari libur dan akhir pekan, dengan kapasitas 15-20 orang per pondoknya sedangkan pada hari kerja disesuaikan dengan kesepakatan antara pemilik pondok dan wisatawan.

\section{Kunjungan Wisata \& Parkir}

Penelitian dilakukan pada saat hari libur nasional, kunjungan wisatawan didekati dengan banyaknya kendaraan yang masuk ke Kawasan Wisata Pantai Pulisan sebagaimana yang tercantum pada karcis parkir. Kendaraan yang masuk terbagi dalam tiga kategori kendaraan yaitu motor, mobil dan bus/truk. Berikut ini adalah data yang dikumpulkan dapat dilihat pada Tabel 5.

Tabel 5. Pendapatan Desa dari Biaya Parkir dan Bea Masuk Kawasan Pulisan September 2016

\begin{tabular}{lcc}
\hline \multicolumn{1}{c}{ Jenis Kendaraan } & $\begin{array}{c}\text { Tarif Parkir } \\
(\mathrm{Rp})\end{array}$ & $\begin{array}{c}\text { Pendapatan } \\
(\mathrm{Rp})\end{array}$ \\
\hline Motor & 5.000 & 365.000 \\
Avanza/Sejenis & 15.000 & 3.720 .000 \\
Bus/Truk & 30.000 & 660.000 \\
\hline Total Pendapatan Parkir & & 4.745 .000 \\
\hline \hline
\end{tabular}

Sumber : Data Olahan 2016

Lahan Parkir di Kawasan ini bisa menampung sampai sekitar 73 buah sepeda motor,248 buah mobil dan 22 buah bus sedang. Berdasarkan jumlah kendaraan ini maka diperkirakan jumlah wisatawan yang berkunjung dapat dilihat pada Tabel 6.

Tabel 6. Jumlah Wisatawan yang berkunjung ke Kawasan Pantai Pulisan September 2016

\begin{tabular}{lrrr}
\hline \multicolumn{1}{c}{$\begin{array}{c}\text { Jenis } \\
\text { Kendaraan }\end{array}$} & $\begin{array}{c}\text { Kapasitas } \\
\text { (orang) }\end{array}$ & \multicolumn{1}{c}{$\begin{array}{c}\text { Jumlah } \\
\text { Kendaraan }\end{array}$} & $\begin{array}{c}\text { Jumlah } \\
\text { Wisatawan }\end{array}$ \\
\hline Sepeda Motor & 2 & 73 & 146 \\
Mobil & 6 & 248 & 1.488 \\
Bus & 22 & 27 & 594 \\
\hline Jumlah & & & 2.228 \\
\hline
\end{tabular}

Sumber : Data Olahan
Selain dari parkir yang memberikan kontribusi sepenuhnya bagi desa pondok/gazebo. Luasan yang diperkenankan oleh desa yaitu 30 meter persegi (dengan ukuran 6 meter x 5 meter) dengan kapasitas 20-30 orang. Meja dan bangku pantai, juga memberikan pendapatan baik bagi desa dan penduduk desa yang menyediakan amenities bagi wisatawan. Pondok dan perahu memberikan kontribusi sebesar Rp 5000 untuk hari-hari libur. Terdapat lebih dari 30 rumah tangga yang terlibat dalam pengelolaan kawasan wisata Pulisan. Jika setiap motor, mobil serta bus diisi penuh maka berikut ini adalah perkiraan pengunjung Pantai Pulisan adalah sekitar 2.476 orang pada saat akhir pekan. Jika semua orang menggunakan kamar mandi untuk bilas dan setiap orang diasumsikan menggunakan 10 liter air maka air yang digunakan sekitar 24.760 liter.

Tabel 7. Jenis Usaha yang ada di Kawasan Pantai Pulisan Tahun 2016

\begin{tabular}{lccc}
\hline Jenis Usaha & Jumlah & $\begin{array}{c}\text { Sewa/Unit } \\
(\mathrm{Rp})\end{array}$ & $\begin{array}{c}\text { Pendapatan } \\
(\mathrm{Rp})\end{array}$ \\
\hline Pondok/ Gazebo & 17 & 250.000 & 4.250 .000 \\
Meja & 33 & 50.000 & 1.650 .000 \\
\hline \hline
\end{tabular}

Sumber : Data Desa Pulisan (2016)

Pengelolaan Kawasan wisata Pulisan diselenggarakan oleh Pemerintah Desa dan Masyarakat. Pemerintah desa menugaskan aparatnya untuk mengkoordinasi penanganan tamu terutama pada parkiran di Kawasan Wisata ini. Pos jaga parkir dijaga oleh 3 orang perangkat desa untuk tugas menjaga pos parkir ini ditugaskan kepada 3 orang dengan shift untuk setiap harinya. 1orang didepan kantor hukum tua menggunakan Handy Talkie mengkomunikasikan bilamana ada tamu yang datang maka penjaga di pos parkir akan mempersiapkan tiket untuk wisatawan kemudian seorang lagi di tempat parkir yang mengatur kendaraan parkir dan mengambil karcis parkir sebagai pengawasan bahwa kendaraan telah melakukan pembayaran parkir di Pos Penjagaan Parkir.

Pemesanan tempat duduk dan meja tidak ada prosedur dalam penanganannyadalam penanganannya. Hanya jika pemilik pondok/gazebo bisa dimintai nomor untuk dihubungi apabila sewaktu-waktu akan datang ke Kawasan Wisata Ini. 


\section{Demografi Wisatawan}

Demografi wisatawan adalah gambaran umum mengenai wisatawan yang datang ke Pulisan. Demografi wisatawan menjelaskan profil dari wisatawan seperti jenis kelamin, umur, tingkat pendidikan, kegiatan, status perkawinan jumlah anggota keluarga dan komposisinya dan tipe keluarga.

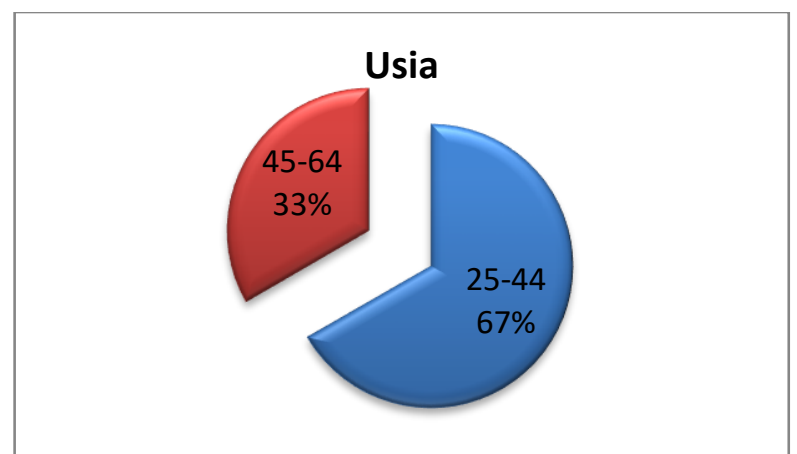

Gambar 1. Usia Wisatawan di Kawasan Pantai Pulisan bulan Agustus tahun 2016

Sebaran usia wisatawan yang mengunjungi Pantai Pulisan sebagian besar berusia 25-44 tahun sebesar 67 persen sedangkan untuk usia 45-64 tahun 33 persen (\%).Sebagian besar pengunjung berusia produktif (25-44 tahun) hal ini sehbungan dengan kondisi tempat wisata yang berbukit dan lokasi pantai yang terpisah tidak dalam satu kawasan, maka untuk menikmati dan mencapai tempat wisata tersebut diperlukan kondisi fisik wisatawan.

Wisatawan yang berusia diatas 45 tahun biasanya hanya menikmati pantai besar tidak lagi mengunjungi pantai yang ada di seluruh kawasan. Wisatawan kelomok umur ini biasanya hanya duduk menikmati keindahan pantai besar sambilmemperhatikan aktivitas wisatawan lainnya serta atraksi yang dilakukan di pantai besar.

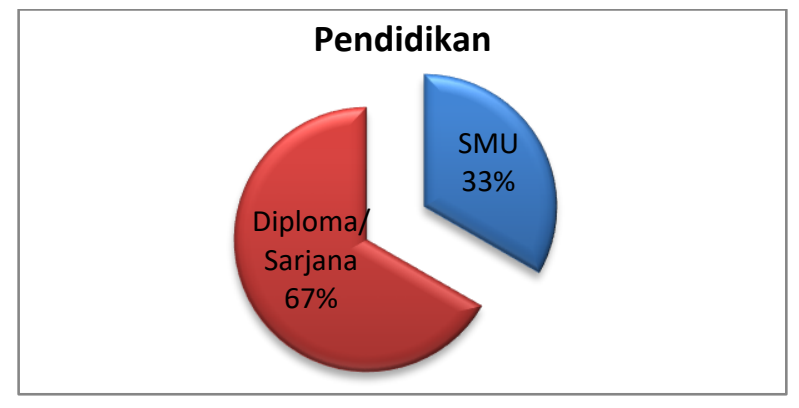

Gambar 2. Tingkat Pendidikan Responden Wisatawan Di Pantai Pulisan bulan Agustus tahun 2016
Responden wisatawan yang datang ke Pulisan dari sebanyak 67 persen berpendidikan diploma dan sarjana, serta 33\% lulusan SMU atau setaranya. Ketika penelitian ini dilakukan ternyata sebagian besar yang terambil sebagai sampel berpendidikan sarjana, mereka pemimpin kelompok wisatawan, baik dari organisasi gereja, maupun dari organisasi social kemasyarakatan (rukun), sedangkan yang berpendidikan setara sekolah menengah atas (SMA) biasanya kelompok wisatawan yang terdiri dari teman-teman sekolah, tetapi ada juga yang merupakan bagian dari kelompok organisasi gereja ataupun organisasi kemasyarakatan.

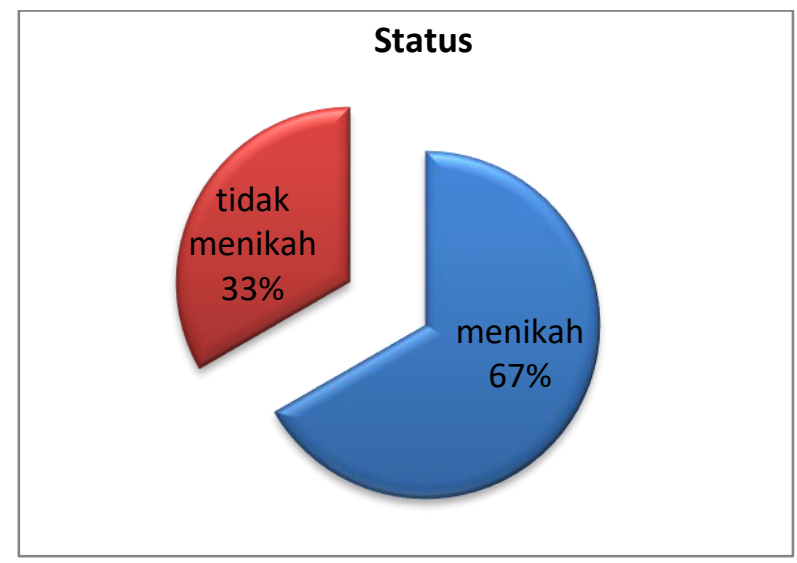

Gambar 3. Status Perkawinan Responden Wisatawan Di Pantai Pulisan bulan Agustus tahun 2016

Status perkawinan responden wisatawan yang mengunjungi Pulisan 67\% sudah menikah dan $33 \%$ belum menikah. Hal ini sesuai dengan pengamatan bahwa kelompok wisatawan yang datang berkunjung sebagian besar bersama dengan keluarga mereka.Wisatawan dapat menikmati atraksi yakni keindahan pantai pulisan bersama keluarga baik dalam pondok wisata, di bangku pantai maupun duduk di pasir bersama dengan keluarga.Kondisi Pantai Pulisan yang menyuguhkan keindahan pantai memungkinkan wistaan untuk menikmatinya bersama keluarga.

Selain itu status pernikahan dari responden ini juga menggambarkan tempat wisatayang seperti apa yang tersedia di Pantai Pulisan. Tempat wisata yang nyaman untuk dinikmati bersama keluarga dan juga public, karena tanpa biaya masuk (murah) serta terbuka. 


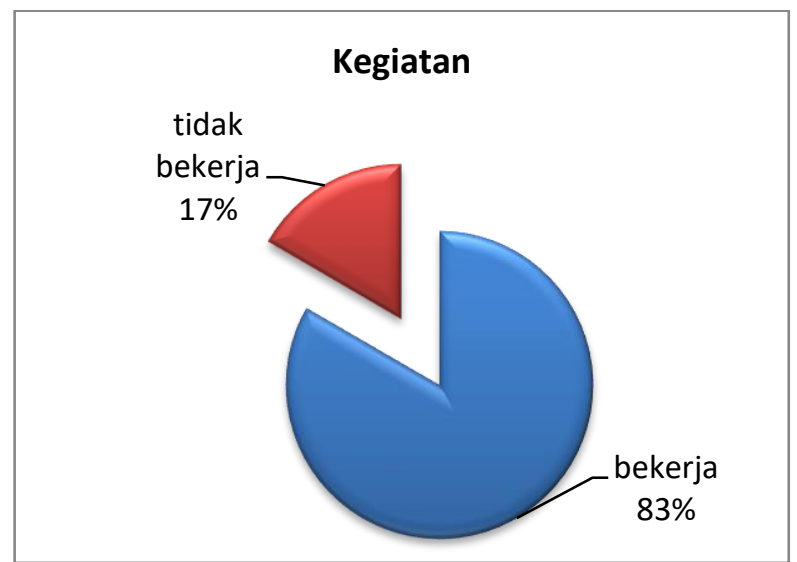

Gambar 4. Aktivitas Responden Wisatawan Di Pantai Pulisan bulan Agustus tahun 2016

Sebagian besar responden 83 persen memiliki pekerjaan dan sebagain kecil 17 persen belum atau tidak bekerja. Hal ini menunjukkan bahwa sebagian besar pengunjung memiliki pekerjaan dan juga penghasilan. Penelitian ini dilakukan ketika masa liburan nasional dimana semua instansi dan lembaga sedang libur, sehingga para pekerja memanfaatkan waktu tersebut untuk menikmati liburan mereka.Pantai Pulisan menjadi pilihan mereka untuk menikmati waktu libur bersama keluarga, selain keindahan pantainya, dan juga biaya yang dikeluarkan relatif murah karena hanya membayar biaya parkir saja wisatawan sudah bisa menikmati keindahan alam Pantai Pulisan.

\section{Jenis Wisatawan}

Berbagai macam tipologi wisatawan telah dikembangkan dengan menggunakan klasifikasi. Klasifikasi wisatawan ini dikemukakan para ahli dengan pendekatan interaksi Cohen (1972) mengklasifikasikan wisatawan atas dasar tingkat familiarisasi dari perjalanan wisatanya. Klasifisikasi wisatawan menurut Cohen dalam tesis ini diadaptasi berdasarkan jawaban responden.

Jenis wisataan sebagian besar merupakan incipient yakni wisatawan yang datang dengan kelompok atau group berjumlah banyak. Hal ini sesuai dengan apa yang telah diuraikan sebelumnya bahwa waktu wawancara adalah waktu libur nasional sehingga memungkinkan wisatawan datang dengan kelompok besar. Selain waktu juga biaya yang dikeluarkan lebih hemat dengan kelompok besar, karena biaya masuk tempat wisata berdasarkan banyaknya dan jenis kendaraan yang masuk ke kawasan bukan berdasarkan Jumlah wisatawan. Hanya sebagian kecil saja yang merupakan wisatawan drifter, yang datang sendiri secara individual bukan bersama kelompok atau group. Tidak tersedianya sarana transportasi umum menuju tempat wisata juga bisa mempengaruhi jenis wisatawan yang berkunjung. Jika tersedia sarana transportasi public mungkin akan banyak drifter yang berkunjung ke kawasan wisata Pulisan.

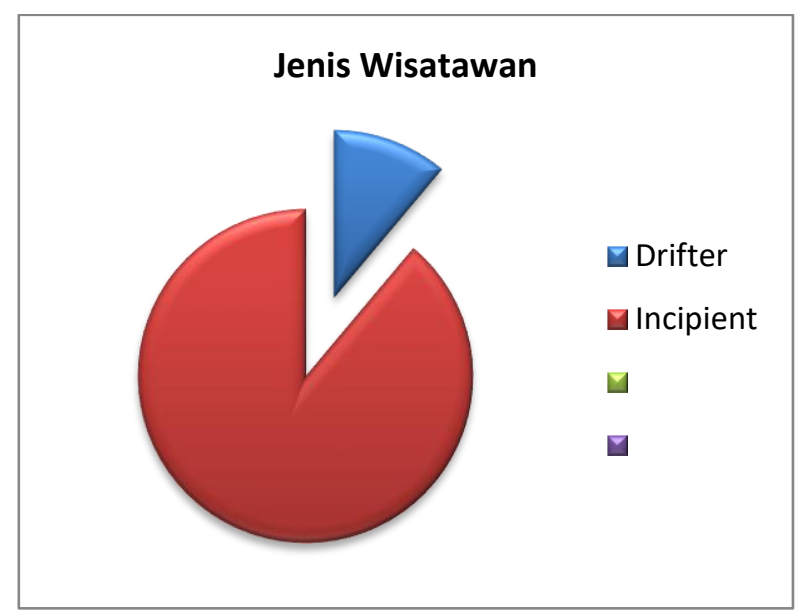

Gambar 5. Jenis Wisatawan Di Pantai Pulisan bulan Agustus tahun 2016

\section{Komposisi Derah Asal Wisatawan}

Wisatawan domestik datang dari berbagai tempat, yakni dari 3 daerah sekitar kawasan yang menjadi tempat asal wisatawan yaitu Manado, Bitung Minahasa Utara dan Jakarta. Persentasenya adalah $63 \%$ berasal dari Manado, $13 \%$ dari Jakarta, 13\% dari Minahasa Utara dan $13 \%$ dari Bitung.

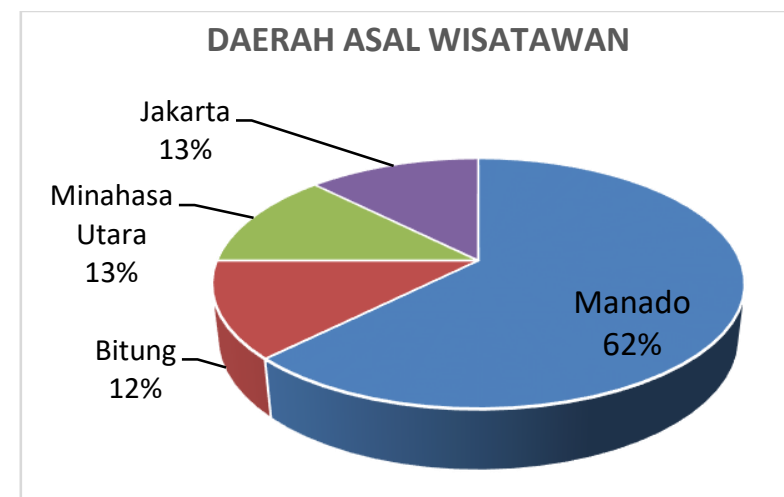

Gambar 6. Daerah Asal Responden Wisatawan Di Pantai Pulisan bulan Agustus tahun 2016

Responden yang datang dari Jakarta khusus untuk mengunjungi Kawasan Pantai 
Pulisan, informasi tentang Pantai Pulisan diperolehnya dari internet. Sedangkan yang dari wilayah provinsi Sulawesi Utara informasi tentang Pantai Pulisan diperolehnya dari teman, sahabat maupun saudara, dan sebagian dari media sosial yang ada.

Alasan kedatangan mereka untuk menyaksikan keindahan Pantai Pulisan serta mengambil foto dan juga menikmati kawasan ini baik hanya dengan duduk di pantai, ataupun mengunjungi pantai lainnya yang ada di kawasan ini.

\section{Komponen Wisata Kawasan Wisata Pulisan}

Mason dan Poerwanto dalam Suryadana dan Oktavia telah merumuskan tentang komponen-komponen produk wisata. Apabila kawasan wisata diposisikan sebagai suatu produk yang akan dipasarkan maka komponen yang ada di Kawasan Wisata Pulisan adalah sebagai berikut

Atraksi : Pantai Besar Pulisan, Pantai Goa, Pantai Pasir Panjang dan Pantai Pulisan II

Aksesibilitas : Angkutan umum (angkot), Bus Pariwisata, Kendaraan Pribadi, Perahu

Amenities : Kios, warung makan, tempat duduk, banana boat

Atraksi yang tersedia di Kawasan Pantai Pulisan yakni Pantai Besar, Pantai Goa, Pantai Pasir Panjang dan Pantai Pulisan II, dimana Pantai Besar merupakan tempat masuk wisatawan, sedangkan untuk ke pantai lainnya harus melalui Pantai Besar dengan menggunakan perahu sebagai sarananya. Keempat pantai ini memiliki keunikan dan keindahannya.

Pantai Besar sebaga i pintu masuk dan penampung wisatawan, dimana dilengkapi kios, warung makan, tempat duduk dan banana boat sebagai amenitasnya.Di Pantai Besar juga terdapat beberapa toilet dan kamar mandi bilas dengan kondisi kebersihan yang memadai dan air bersih yang tersedia dalam Jumlah yang banyak.

Hal ini memudahkan bagi pengunjung untuk merasa nyaman karena tersedianya sarana tersebut.
Ketiga pantai lainnya, Pantai Goa untuk menikmati keindahan dan tantangan untuk mencapai lokasi ini, sedangkan Pantai Panjang dan Pantai Pulisan 2, untuk mandi dan bermain air karena kejernihan dan kebersihan air lautnya serta topografinya yang memungkinkan dan menjamin keamanan bagi para wisatawan termasuk anak-anak.

Kawasan Wisata Pulisan dapat dicapai dengan berbagai moda transportasi mulai dari roda dua, roda empat, dan bus reguler yang dapat disewa untuk rombongan. Kapasitas bus yang biasa digunakan 27 orang dan bus jenis ini lebih murah dibandingkan bus pariwisata. Untuk charter antar dan jemput dikenakan biaya sebesar Rp 700.000,00.

\section{Rumah Tangga Penyedia Jasa di Kawasan Wisata Pulisan}

Kegiatan berwisata di Pulisan didukung oleh masyarakat setempat dengan adanya berbagai fasilitas untuk memenuhi kebutuhan para wisatawan. Responden rumah tangga penyedia jasa yang ada di Kawasan Pantai Pulisan sebanyak 11 kepala keluarga. Data yang telah diperoleh menunjukkan 11 kepala keluarga responden yang ikut serta dalam menyediakan jasa di Kawasan Wisata Pulisan. Data mengenai usaha yang dijalankan di Kawasan Wisata tersebut secara rinci dapat dilihat pada Tabel 9, data tersebut menggambarkan pendapatan yang mereka peroleh ketika hari kerja (weekdays) dan ketika akhir pekan (weekend), dari keluarga responden yang ikut serta dalam pengelolaan Kawasan Wisata Pulisan terdapat 5 (lima) jenis usaha yang dijalankan oleh warga Pulisan antara lain: Kantin, penyewaan meja dan bangku, penyewaan pondok, toilet, atraksi banana boat, penyewaan perahu, dan penyewaan alat snorkelling.

Tabel 10 menunjukkan modal yang dikeluarkan oleh warga untuk membuat fasilitas wisata di Pantai Pulisan, dan pendapatan yang diperolehnya serta lamanya berusaha. 
Tabel 8. Jenis Usaha, Modal dan Pendapatan Keluarga Pengelola Usaha Di Kawasan Pantai Pulisan

\begin{tabular}{|c|c|c|c|c|c|c|c|}
\hline \multirow[t]{2}{*}{ No } & \multirow[t]{2}{*}{ Nama } & \multirow{2}{*}{$\begin{array}{l}\text { Jenis } \\
\text { Usaha }\end{array}$} & \multirow[t]{2}{*}{ Modal } & \multicolumn{2}{|c|}{ Pendapatan } & \multirow{2}{*}{$\begin{array}{c}\text { Lama } \\
\text { Buka } \\
\text { Usaha }\end{array}$} & \multirow{2}{*}{$\begin{array}{c}\text { Pekerjaan } \\
\text { Sebelum-nya }\end{array}$} \\
\hline & & & & Weekday & Weekend & & \\
\hline \multirow[t]{3}{*}{ 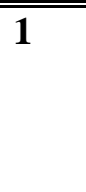 } & $\overline{\text { Ratna }}$ & "Kantin & "10.000.000 & 400.000 & 2000.000 & 3 tahun & 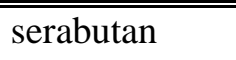 \\
\hline & Lakuhati & & 400.000 & & & & \\
\hline & & & 400.000 & & & & \\
\hline \multirow[t]{2}{*}{2} & Berci & Meja & 400.000 & & 100.000 & 3 bulan & berkebun \\
\hline & Togelang & & & & & & \\
\hline \multirow[t]{3}{*}{3} & Ibu Rosiana & Meja & 400.000 & & 100.000 & 3 bulan & berkebun \\
\hline & Patilona & Tenda & 500.000 & & 200.000 & 1 tahun & berkebun \\
\hline & Bindara & kantin & & & 100.000 & & \\
\hline \multirow[t]{3}{*}{4} & Bindara Hati & Kios & 1.000 .000 & & 1.000 .000 & 1 tahun & Menganggur \\
\hline & & Kamar & 300.000 & & 600.000 & & \\
\hline & & Mandi & & & & & \\
\hline \multirow[t]{3}{*}{5} & Bindara Hari & Kios & 1.000 .000 & & 1.000 .000 & 1 tahun & Menganggur \\
\hline & & Kamar & & & 600.000 & & \\
\hline & & Mandi & & & & & \\
\hline \multirow[t]{2}{*}{6} & Karutabe & Warung & 1.000 .000 & & 2.000 .000 & 1 tahun & Menganggur \\
\hline & Kauntu & Gazebo & 5000.000 & & 250.000 & & \\
\hline \multirow[t]{3}{*}{7} & Lumahu & Kios & 1.000 .000 & & 1.000 .000 & 1 tahun & Menganggur \\
\hline & Bawata & Kamar & 300.000 & & & & \\
\hline & & Mandi & & & & & \\
\hline \multirow[t]{2}{*}{8} & Lungkang & Warung & 500.000 & & 1.000 .000 & 1 tahun & Menganggur \\
\hline & Dalope & Gazebo & 200.000 & & 100.000 & & \\
\hline \multirow[t]{3}{*}{9} & Togelang & Kios & 5.000 .000 & & 3.000 .000 & 1 tahun & Menganggur \\
\hline & Anza & Kamar & 300.000 & & & & \\
\hline & & Mandi & & & & & \\
\hline \multirow[t]{3}{*}{10} & Ferdinand & Kios & 2.500 .000 & & 500.000 & & Menganggur \\
\hline & Takapohe & Kamar & 300.000 & & 300.000 & & \\
\hline & & Mandi & & & & & \\
\hline \multirow[t]{3}{*}{11} & Tatara & Tenda & 3.000 .000 & & 1.000 .000 & 1 tahun & Menganggur \\
\hline & Mangadil & Kios & & & & & \\
\hline & & Gorengan & & & & & \\
\hline
\end{tabular}

Sumber: Data Olahan 


\section{Deskripsi Pondok Wisata}

Terdapat sekitar 17 Pondok Wisata yang dikelola masyarakat desa Pulisan. Bahan dan desainnya pun bervariasi dengan biaya pembuatan yang rendah mulai dari Rp.200.000 sampai Rp.5.000.000.

Pondok yang memiliki biaya paling murah adalah pondok dengan bahan bambu karena tidak perlu membeli dan hanya biaya pembuatan saja atau bahkan dibuat sendiri oleh warga setempat.

Kombinasi bahan yang dipakai untuk konstruksi pondok yang dipakai bermacammacam 3 (tiga) gazebo bantuan pemerintah berbahan kayu dengan atau genteng metal dan 5 (lima) gazebo lainnya berbahan bambu dengan atap nipah, dan ada pula yang terbuat dari kayu dan atap seng. Tiap $6 \times 5 \mathrm{~m}^{2}$ terdapat 17 pondok yang menghabiskan tempat $510 \mathrm{~m}^{2}$.

Hasil wawancara dengan Kepala Seksi Dinas Pariwisata Minahasa Utara, beliau menjelaskan bahwa paling lambat Desember 2016 desain bangunan sudah harus diperbarui oleh warga setempat karena beberapa ada yang terbuat dari tenda terkesan kumuh.

Hal yang perlu ditekankan disini bukan pada bagaimana cara membangun fasilitas akan tetapi bagaimana dengan biaya yang sangat rendah kebutuhan para wisatawan dapat dipenuhi, memberikan pengalaman tersendiri dari para wisatawan dan yang terpenting memberikan manfaat ekonomi bagi masyarakat setempat.

\section{Analisis Faktor Internal}

1. Keindahan Alam: Kawasan Wisata Pulisan Memiliki 3 Pantai Unggulan yaitu Pantai Besar Pulisan, Pantai Goa dan Pantai Pasir Panjang. Garis Pantai yang panjang dengan pasir putih terbentang lebih dari $400 \mathrm{~m}$. Pantai dengan banyak kegiatan wisata seperti berenang, naik perahu hunting photo, berjemur snorkelling dan freedive.
2. Atraksi banana boat yang diminati pengunjung dengan durasi yang cukup dan harga yang terjangkau.

3. Tersedia air bersih untuk pelayanan jasa bilas dan mandi.

4. Informasi yang dimaksud adalah dengan kemajuan teknologi saat ini Kawasan Wisata Pulisan bisa diakses dengan fasilitas Global Positioning System (GPS) di internet serta berbagai ulasan di blog dan media sosial.

5. Pengelolaan parkir yang dilakukan sepenuhnya oleh warga desa masih belum dilakukan secara profesional.

6. Fasilitas makanan dan minuman yang masih seadanya dan kurang diminati oleh wisatawan.

7. Aksesibilitas kawasan wisata ini hanya bisa dicapai dengan kendaraan pribadi, belum terjangkau oleh angkutan umum.

8. Kondisi jalan meuju pulisan yang rusak berat dan sempit menyulitkan bagi wisatawan.

9. Kebersihan pantai ini masih kurang dijaga dengan baik.

\section{Analisis Faktor Eksternal}

1. Kebijakan pemerintah yang mendukung pengembangan pariwisata yang berbasis masyarakat. Usaha pariwisata bebas dari retribusi.

2. Penerbangan dari negara Tiongkok memberikan peluang wisatawan mancanegara.

3. Hotel berbintang dan melati bintang yang tersedia baik di Manado dan Minahasa Utara

4. Cuaca ekstrim yang melanda pada waktu-waktu tertentu yang sangat berpengaruh pada wisata bahari.

5. Pengembangan yang dilakukan secara swadaya masyarakat belum terpola.

6. Sosialisasidari pemerintah masih kurang mengenai rencana pembangunan.

7. Kawasan wisata alam disekitar Pulisan yang sudah dikembangkan. 


\section{Analisis SWOT}

Tabel $9 \quad$ Matriks SWOT

\begin{tabular}{|c|c|c|}
\hline & $\begin{array}{l}\text { Kekuatan } \\
\text { 1. Potensi Alam } \\
\text { 2. Ketersediaan air Bersih } \\
\text { 3. Pengelolaan Parkir } \\
\text { 4. Informasi }\end{array}$ & $\begin{array}{l}\text { 1. Aksesibilitas } \\
\text { 2. Kebersihan } \\
\text { 3. Kualitas SDM }\end{array}$ \\
\hline $\begin{array}{ll}\text { Kesempatan } \\
\text { 1. } & \text { Kebijakan Pemerintah } \\
\text { 2. } & \text { Penerbangan dari RRC } \\
\text { 3. } & \text { Sarana Akomodasi } \\
& \text { disekitar Kawasan }\end{array}$ & $\begin{array}{l}\quad \text { Strategi SO } \\
\text { 1. Penentuan Kawasan } \\
\text { 2. Menyediakan jaringan air } \\
\text { bersih }\end{array}$ & $\begin{array}{l}\text { Strategi SW } \\
\text { 1. Bantuan untuk pembangunan jalan masuk } \\
\text { ke kawasan wisata } \\
\text { 2. Pelatihan kepada warga setempat } \\
\text { 3. Pelatihan untuk warga desa }\end{array}$ \\
\hline $\begin{array}{l}\text { Ancaman } \\
\text { 1. Cuaca } \\
\text { 2. Persaingan dengan } \\
\text { Kawasan wisata sejenis }\end{array}$ & $\begin{array}{l}\quad \text { Strategi ST } \\
\text { 1. Pembangunan } \\
\text { infrastruktur yang lebih } \\
\text { representatif }\end{array}$ & \begin{tabular}{l}
\multicolumn{1}{c}{ Strategi WT } \\
1. Penggunaan Kendaraan segala medan. \\
2. Pengorganisasian Ulang untuk Petugas \\
Pantai oleh Perangkat Desa. \\
3. Menggunakan tenaga kerja yang lebih \\
profesional
\end{tabular} \\
\hline
\end{tabular}

Tabel 10 IFAS (Internal Strategic Factor Analysis Strategy)

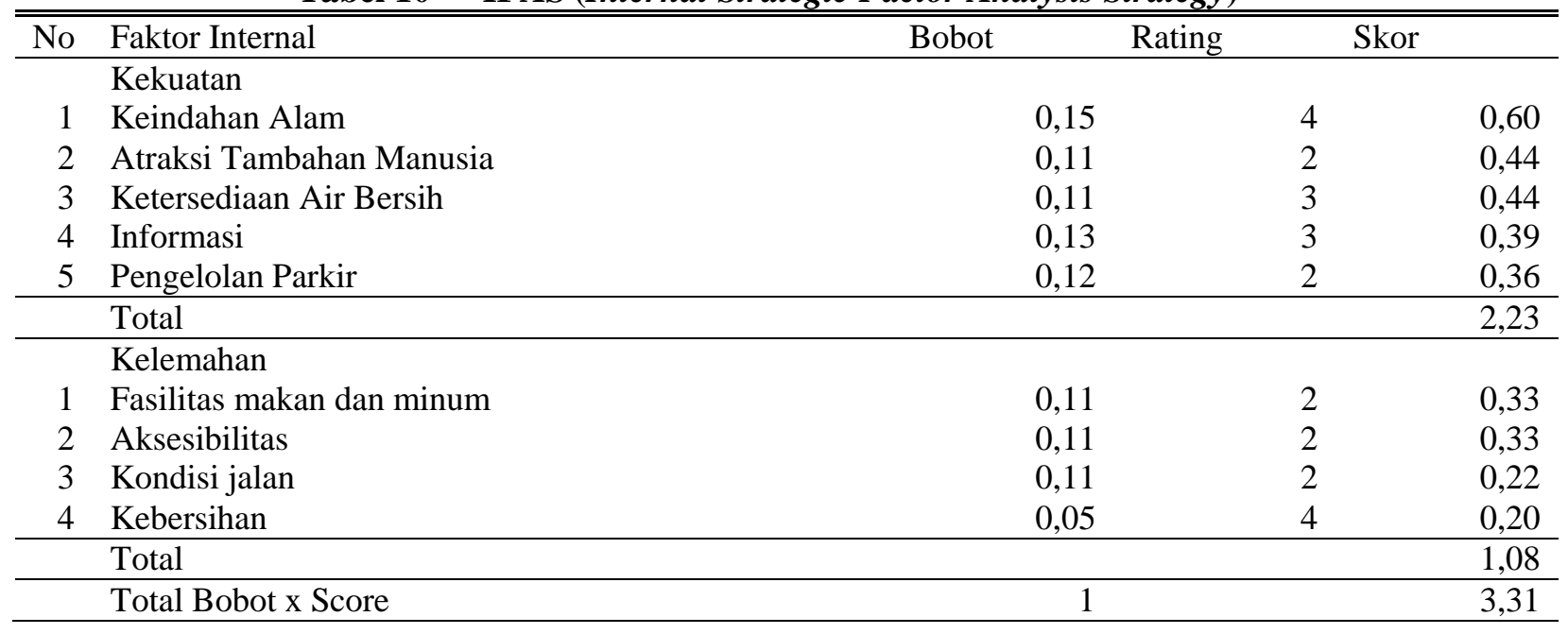

Tabel 11 EFAS (External Factor Strategic Analysis)

\begin{tabular}{lrrr}
\hline \hline Faktor Eksternal & Bobot & Rating & Skor \\
\hline Peluang & & & \\
KebijakanPemerintah & 0,14 & 1 & 0,42 \\
Dibukanya penerbangan dari China & 0,13 & 2 & 0,26 \\
Hotel berbintang dan non bintang & 0,07 & 2 & 0,28 \\
Akses Ke Bandara & 0,11 & 2 & 0,44 \\
Respon Masyarakat Setempat & 0,12 & 2 & 0,24 \\
\hline Total (a) & & & 1,64 \\
\hline Ancaman & & & \\
Cuaca & 0,18 & 1 & 0,18 \\
Sosialiasi dari pemerintah daerah & 0,12 & 2 & 0,24 \\
Persaingan dengan Kawasan Wisata Sejenis & 0,13 & 3 & 0,52 \\
\hline Total (b) & & & 0,94 \\
\hline Total (a+b) & 1 & 2,58 \\
\hline
\end{tabular}


Tabel 12 Matrix Space Analysis

\begin{tabular}{|c|c|c|c|c|}
\hline No & Faktor Internal & Bobot & Rating & Skor \\
\hline & Kekuatan & & & \\
\hline 1 & Keindahan Alam & 0,15 & 4 & 0,60 \\
\hline 2 & Atraksi Tambahan Manusia & 0,11 & 2 & 0,22 \\
\hline 3 & Ketersediaan Air Bersih & 0,11 & 3 & 0,33 \\
\hline 4 & Informasi & 0,13 & 3 & 0,39 \\
\hline \multirow[t]{3}{*}{5} & Pengelolan Parkir & 0,12 & 2 & 0,36 \\
\hline & Total & & & 1,90 \\
\hline & Kelemahan & & & \\
\hline 1 & Fasilitas makan dan minum & 0,11 & 2 & $-0,22$ \\
\hline 2 & Aksesibilitas & 0,11 & 2 & $-0,22$ \\
\hline 3 & Kondisi jalan & 0,11 & 2 & $-0,22$ \\
\hline \multirow[t]{3}{*}{4} & Kebersihan & 0,05 & 4 & $-0,20$ \\
\hline & Total & & & $-0,86$ \\
\hline & Total Bobot x Score & 1 & & 1,04 \\
\hline \multirow[t]{2}{*}{ No } & Faktor Eksternal & Bobot & Rating & Skor \\
\hline & Peluang & & & \\
\hline 1 & KebijakanPemerintah & 0,14 & 3 & 0,42 \\
\hline 2 & Dibukanya penerbangan dari China & 0,13 & 2 & 0,26 \\
\hline 3 & Hotel berbintang dan non bintang & 0,07 & 4 & 0,28 \\
\hline 4 & Akses Ke Bandara & 0,11 & 4 & 0,44 \\
\hline \multirow[t]{3}{*}{5} & Respon Masyarakat Setempat & 0,12 & 2 & 0,24 \\
\hline & Total & & & 1,64 \\
\hline & Ancaman & & & \\
\hline 1 & Cuaca & 0,18 & 1 & $-0,18$ \\
\hline 2 & Sosialiasi dari pemerintah daerah & 0,12 & 2 & $-0,24$ \\
\hline \multirow[t]{3}{*}{3} & Persaingan dengan Kawasan Wisata Sejenis & 0,13 & 4 & $-0,52$ \\
\hline & Total & & & $-0,94$ \\
\hline & Total Bobot x Rating & 1 & & 0,7 \\
\hline
\end{tabular}

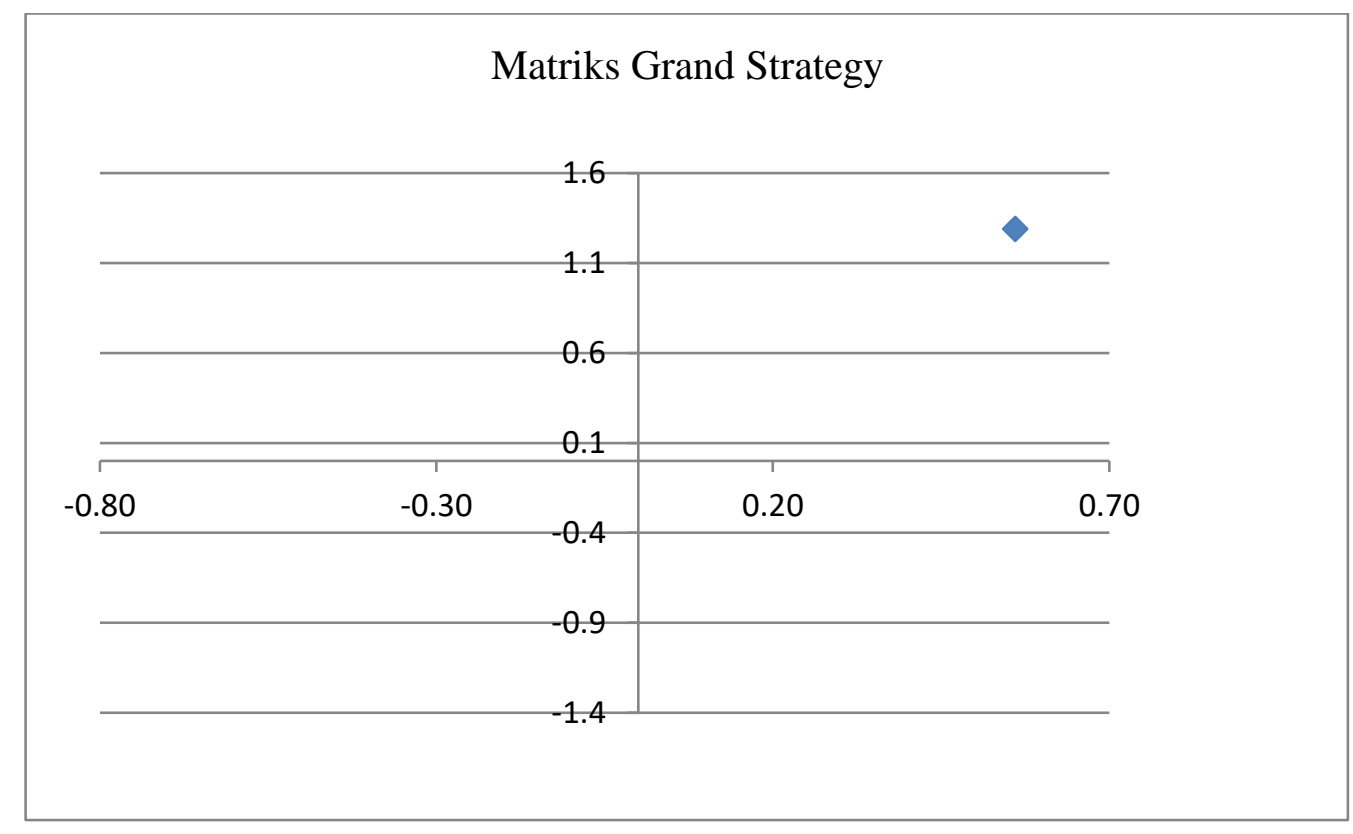


Matrix grand strategy menunjukkan strategi pengembangan kawasan berada di kwadran I strategi yang digunakan adalah strategi pertumbuhan (growth strategy). Pertumbuhan kunjungan wisatawan yang datang ke Kawasan Wisata dengan strategi ini bisa dilakukan dengan menyediakan layanan yang lebih berkualitas, mengembangkan atraksi-atraksi, atraksi pertunjukan atau atraksi-atraksi seperti olah raga air serta fasilitas lainnya untuk menikmati pemandangan alam. Oleh karena wisatawan datang berkunjung ke Pulisan 33\% berusia 44-65 tahun harus dipertimbangkan kembali sarana rekreasi yang menunjang agar alam dari kawasan wisata ini bisa lebih dinikmati oleh wisatawan. Perasaan aman dan nyaman serta kebutuhan dari wisatawan sebaiknya dipenuhi agar kunjungan wisatawan bisa lebih lama dan memberikan pengalaman tersendiri.

\section{KESIMPULAN}

Hasil analisis SWOT (Strength, Weakness, Oportunity, Threat) menunjukkan bahwa Kawasan Wisata Pulisan adalah Kawasan Wisata dengan potensi alam yang tinggi dan banyak diminati oleh wisatawan. Walaupun dengan Lokasi yang tidak terlalu luas namun banyak memiliki atraksi yang menarik Kawasan Wisata alam Pulisan menarik bagi berbagai jenis wisatawan dengan motivasi yang berbeda pula. Pengembangan yang dilakukan oleh masyarakat dengan pembinaan yang dilakukan oleh Dinas Pariwisata dan Kebudayaan Minahasa Utara memberikan perubahan dari segi desain fasilitas wisata. Penataan ulang dengan mempertimbangkan prioritas akan kebutuhan wisatawan di Kawasan Wisata ini akan sangat berpengaruh pengembangannya, sehingga wisatawan dan pelancong dapat merasakan value dari sebuah Kawasan Wisata Bahari dengan harga yang terjangkau. Strategi pertumbuhan yang digunakan memberikan manfaat bagi warga setempat. Kunjungan wisatawan yang tinggi setiap akhir pekan diharapkan bisa memberikan warga setempat kemampuan untuk mengembangkan, hanya saja perlu pembinaan dari dinas terkait untuk memberikan pengembangan yang lebih terarah.

\section{DAFTAR PUSTAKA}

Adisasmita, Raharjo. 2014. Ekonomi Tata Ruang Wilayah.Yogyakarta: Graha Ilmu

Anonim. 1990. Undang - Undang tentang Kepariwisataan. Jakarta: DPR

Anonim. 2014. Destination Development \& Marketing Plan.Prince George Society

Badan Pusat Statistik.2014.Sulawesi Utara Dalam Angka.Manado: BPS

Utara: BPS 2015.Statistik Likupang Barat.Minahasa

2015.Kecamatan Likupang Barat Dalam Angka. Minahasa Utara: BPS

Badrudin, Rudy.2012.Ekonomika Otonomi Daerah.Yogyakarta: UPP STIM YKPN

Buono, Agus DKK.2001.Pedoman Penulisan \&Penyajian Karya Ilmiah.Bogor: IPB Press

Hadi, Sudarto P.2014.Manajemen Lingkungan.Yogyakarta: Dua Satria Offset

Hasan, Ali.2015.Tourism Marketing. Yogyakarta: CAPS

International Labour Organizations. 2012. Sustainable Tourism for Green Jobs.Jakarta: ILO

Kodoatie, Robert dan Sjarief. 2010. Tata Ruang Air.Yogyakarta: Andi

Nasution, S.2007. Metode Research (Penelitian Ilmiah).Jakarta: Bumiaksara

Rangkuti, Freddy.2013.Analisis SWOT. Jakarta: Gramedia

Rangkuti, Freddy.2015. Analsis SWOT “Teknik Membedah Kasus Bisnis". Jakarta: Gramedia

Rangkuti, Freddy.1999. Analisis SWOT Teknik Membedah Kasus Bisnis. Jakarta: Gramedia

Stange, Jenniferet al. 2013 Tourism Destination Management. Washington DC: George Washington University

Suryadana, M Liga dan Oktavia, Vanny.2015.Pengantar Pemasaran Pariwisata. Bandung: Alfabeta

Yoeti, Oka A.2008.Ekonomi Pariwisata.Jakarta: Kompas Gramedia 